\title{
THE EFFECT OF LOW BIRTHWEIGHT AND IMMUNIZATION STATUS ON THE RISK OF ACUTE RESPIRATORY INFECTION AT AMBARITA COMMUNITY HEALTH CENTER, SAMOSIR, NORTH SUMATERA
}

\author{
Vina Lindawati Simorangkir'), Etty Sudaryati²), Taufik Ashar3) \\ ${ }^{1)}$ Masters Program in Public Health, Faculty of Public Health, \\ Universitas Sumatera Utara \\ 2)Department of Nutrition, Faculty of Public Health, Universitas Sumatera Utara \\ 3)Department of Environmental Health,Faculty of Public Health, \\ Universitas Sumatera Utara
}

\begin{abstract}
Background: Acute Respiratory Infection (ARI) is the most common disease in children involving the upper respiratory tract and lower respiratory tract. This infection is caused by viruses, fungi, and bacteria. The ARI incidence was estimated 156 million new cases worldwide per year and 151 million cases (96.7\%) occurred in developing countries. ARI was the major causes of patient visits to community health center (40-60\%) and hospitals (15-30\%). This study aimed to examine the effect of low birthweight (LBW) and immunization status onthe risk of acute respiratory infection at Ambarita community health center, Simanindo, Samosir, Sumatera.
\end{abstract}

Subjects and Method: This was a cross-sectional study conducted at Ambarita community health center, Simanindo, Samosir, North Sumatera, in 2017. A sample of 86 children under five was selected for this study from 276 children under five in the source population. The dependent variable was ARI. The independent variables were LBW and immunization status. The data were collected from medical record and questionnaire. The data were analyzed by a multiple logistic regression.

Results: The risk of ARI increased with $\mathrm{LBW}(\mathrm{OR}=110.56,95 \% \mathrm{CI}=7.51$ to $1,627.63 ; \mathrm{p}=0.001)$ and incomplete immunization status $(\mathrm{OR}=34.91 ; 95 \% \mathrm{CI}=$ 4.98 to $244.61 ; \mathrm{p}=0.004)$.

Conclusion: The risk of ARI increases with LBW and incomplete immunization status.

Keywords: acute respiratory infection, low birthweight, immunization, children under five

\section{Correspondence:}

Vina Lindawati Simorangkir. Masters Program in Public Health, Faculty of Public Health, Universitas Sumatera Utara, Jl. Universitas No.21, Kampus USU, North Sumatera, Indonesia.Email: vinalindawatiskmarangkir@gmail.com. 